Michae ILSKI

\title{
Pojęcie przedsiębiorstwa i zorganizowanej części przedsiębiorstwa na gruncie prawa podatkowego
}

\begin{abstract}
Wstęp
$\mathrm{Z}$ pojęciem przedsiębiorstwa oraz zorganizowanej części przedsiębiorstwa $\mathrm{w}$ prawie podatkowym mamy do czynienia na gruncie ustaw o podatkach dochodowych. Ustawa o podatku od towarów i usług natomiast definiuje na swoje potrzeby pojęcie zorganizowanej części przedsiębiorstwa, nie definiując jednak pojęcia samego przedsiębiorstwa (pomimo że się nim posługuje). Oba $\mathrm{z}$ wymienionych pojęć występują $\mathrm{w}$ wielu przepisach ustaw o podatkach dochodowych, a ich znaczenie wpływa na kształt szczegółowych regulacji prawnych. Należy również nadmienić, że pojęcie przedsiębiorstwa oraz jego zorganizowanej części pojawia się także w ustawie o podatku od czynności cywilnoprawnych.
\end{abstract}

\section{Pojęcie przedsiębiorstwa i zorganizowanej części przedsiębiorstwa na gruncie ustaw o podatkach dochodowych}

\section{Definicje ustawowe}

$\mathrm{Na}$ gruncie ustawy o podatku dochodowym od osób fizycznych oraz ustawy o podatku dochodowym od osób prawnych definicja legalna przedsiębiorstwa obowiązuje od dnia 1 stycznia $2003 \mathrm{roku}^{1}$. Obie definicje są identyczne. Zgodnie z nimi przedsiębiorstwo oznacza przedsiębiorstwo w rozumieniu przepisów k. c. (dalej powoływany również jako - k.c.), ustawodawca definiując to pojęcie zastosował technikę odesłania. Zgodnie

1 Definicje dodane mocą ustawy z dnia 27 lipca 2002 r. o zmianie ustawy o podatku dochodowym od osób fizycznych orazo zmianie niektórych innych ustaw (Dz. U. Nr 141, poz. 1182); oraz ustawy z dnia 27 lipca 2002 roku o zmianie ustawy o podatku dochodowym od osób prawnych (Dz. U. Nr 141, poz. 1179). 
z art. 551 k. c. przedsiębiorstwo stanowi zorganizowany zespół składników niematerialnych i materialnych przeznaczonych do prowadzenia działalności gospodarczej. Obejmuje ono w szczególności:

- oznaczenie indywidualizujące przedsiębiorstwo lub jego wyodrębnione części (nazwa przedsiębiorstwa),

- własność nieruchomości lub ruchomości, w tym urządzeń, materiałów, towarów i wyrobów oraz inne prawa rzeczowe do nieruchomości lub ruchomości,

- prawa wynikające $z$ umów najmu i dzierżawy nieruchomości lub ruchomości oraz prawa do korzystania $z$ nieruchomości lub ruchomości wynikające $z$ innych stosunków prawnych,

- wierzytelności, prawa z papierów wartościowych i środki pieniężne,

- koncesje, licencje i zezwolenia,

- patenty i inne prawa własności przemysłowej,

- majątkowe prawa autorskie i majątkowe prawa pokrewne,

- tajemnice przedsiębiorstwa,

- księgi i dokumenty związane z prowadzeniem działalności gospodarczej.

Przez zorganizowaną część przedsiębiorstwa rozumienie się natomiast organizacyjnie i finansowo wyodrębniony w istniejącym przedsiębiorstwie zespół składników materialnych i niematerialnych, w tym zobowiązań, przeznaczonych do realizacji określonych zadań gospodarczych, który zarazem mógłby stanowić niezależne przedsiębiorstwo samodzielnie realizujące te zadania. Definicja ta na gruncie obu ustaw regulujących podatki dochodowe obowiązuje od dnia 1 stycznia 2003 roku.

Ustawodawca podatkowy na gruncie ustaw poświęconych podatkom dochodowym niejednokrotnie sięga do pojęcia przedsiębiorstwa i jego zorganizowanej części. Szczególnego, praktycznego znaczenia w obrocie gospodarczym (zwłaszcza w transakcjach związanych z przekształceniami podmiotów prowadzących działalność gospodarczą) nabiera problem uznania danej masy majątkowej za przedsiębiorstwo lub za jego zorganizowaną część. Skutki takiego uznania są daleko idące. Przykładowo wolne od podatku dochodowego są przychody z tytułu objęcia akcji lub udziałów w zamian za wkład niepieniężny w postaci przedsiębiorstwa lub jego zorganizowanej części - do wysokości wartości nominalnej objętych udziałów lub akcji. Jest to niezwykle korzystne rozwiązanie umożliwiające odroczenie płatności podatku do chwili zbycia akcji lub udziałów. W tym przypadku ustawodawca w sposób szczególny uregulował kwestię kosztów uzyskania przychodu.

W razie odpłatnego nabycia przedsiębiorstwa lub jego zorganizowanej części powstaje zagadnienie związane $z$ ustaleniem wartości firmy, jej amortyzacją, a także amortyzacją przejętych składników majątkowych. $Z$ kolei w przypadku jego nabycia w drodze wkładu niepieniężnego powstaje do rozwiązania problem amortyzacji zawartych w nim składników majątkowych. Zatem, jak wynika z powyższego, pojęcie przedsiębiorstwa 
oraz jego zorganizowanej części może wywoływać szereg wątpliwości, zarówno teoretycznych, jak i praktycznych.

\section{Przedsiębiorstwo i jego zorganizowana część w orzecznictwie sądowym}

W orzecznictwie sądowoadministracyjnym trafnie podnosi się, że posłużenie się przez ustawodawcę przy definiowaniu przedsiębiorstwa odesłaniem do k. c. skutkuje tym, iż wszelkie rozważania na jego temat nie moga abstrahować ani od jego kodeksowego ujęcia, ani też od dorobku doktryny i judykatury w tym zakresie ${ }^{2}$. Prawo cywilne posługuje się pojęciem przedsiębiorstwa w jego ujęciu przedmiotowym, traktując je jako wyodrębniony kompleks majątkowy. Obecny art. $551 \mathrm{k}$. c. nawiązuje zresztą do treści art. 40 przedwojennego Kodeksu Handlowego. Sam charakter prawa do przedsiębiorstwa budzi wiele wątpliwości, które nie mają jednak większego znaczenia na tle regulacji podatkowych. $\mathrm{O}$ wiele bardziej znaczący jest problem możliwości uznania określonej masy majątkowej za przedsiębiorstwo. Okolicznością przesądzającą w tym zakresie wydaje się być możliwość prowadzenia działalności gospodarczej w oparciu o określony substrat majątkowy. Nie można a priori określić jakie składniki muszą zostać objęte treścią czynności prawnej, by móc uznać, że mamy już do czynienia z przedsiębiorstwem. Ocena taka dopuszczalna jest dopiero w realiach danej sprawy ${ }^{3}$. Zgodnie $z$ art. 552 k. c. czynność prawna mająca za przedmiot przedsiębiorstwo obejmuje wszystko, co wchodzi w skład przedsiębiorstwa, chyba że co innego wynika z jej treści albo z przepisów szczególnych. Stroną czynności prawnej mającej za swój przedmiot przedsiębiorstwo przysługuje zatem swoboda w wyłączeniu z zakresu tej czynności określonych jego składników. Swoboda ta nie może jednak prowadzić do tego, aby zakres wyłączeń przekreślał istotę przedsiębiorstwa. Dlatego też, aby mówić o przedsiębiorstwie, określony zespół składników majątkowych musi obejmować te składniki, za pomocą których możliwe jest prowadzenie działalności gospodarczej. ${ }^{4}$ Rozstrzygając zatem, czy w konkretnym stanie faktycznym doszło do przeniesienia własności przedsiębiorstwa, należy ustalić, czy na nabywcę przeszły prawa do takiej sumy zorganizowanych składników materialnych i niematerialnych, w oparciu o którą to sumę możliwe jest prowadzenie działalności gospodarczej. Aby mówić o przedsiębiorstwie w znaczeniu przedmiotowym, konieczne jest występowanie elementu organizacji oraz funkcjonalnego powiązania różnorodnych jego składników w taki sposób, by móc je traktować jako całość ${ }^{5}$. Przedsiębiorstwo nie jest jedynie prostą sumą składników - składniki te muszą zostać zorganizowane w taki to sposób, aby przy ich pomocy możliwe było prowadzenie działalności gospodarczej ${ }^{6}$. Do

2 Vid. Wyrok WSA w Gdańsku z dnia 19 października 2011 r. sygn. I SA/Gd 737/11.

3 Vid. Wyrok NSA we Wrocławiu z dnia 18 września 2002 r. sygn. I SA/Wr 2713/00.

4 Vid. też: Wyrok SN z dnia 17 października 2000 r. sygn. I CKN 850/98.

5 Cf. Wyrok SN z dnia 3 grudnia 2009 r. sygn. II CSK 215/09.

6 Cf. Wyrok NSA w Krakowie z dnia 24 listopada 1999 r. sygn. I SA/Kr 1189/99. 
nabycia przedsiębiorstwa może dojść w wyniku kilku czynności prawnych ${ }^{7}$ Kryterium przesądzającego o tym, czy dana transakcja ma już za swój przedmiot przedsiębiorstwo, nie może stanowić wartości składnika przedsiębiorstwa w porównaniu $z$ wartością całego przedsiębiorstwa ${ }^{8}$.

W celu rzetelnego wyjaśnienia (choćby w ramach postępowania podatkowego), czy czynność prawna w istocie miała za swój przedmiot przedsiębiorstwo, nie można poprzestawać jedynie na analizie umowy. Brak określenia w umowie spółki przedmiotu aportu jako przedsiębiorstwa nie jest wystarczający dla przyjęcia, że w istocie przedmiotu aportu nie stanowiło przedsiębiorstwo ${ }^{9}$. Podobne stanowisko prezentowane jest na gruncie spraw cywilnych, zgodnie bowiem z jednym z orzeczeń SN dla oceny, czy doszło do nabycia przedsiębiorstwa, nie jest miarodajne dosłowne brzmienie umowy, w tym również nazwanie przez strony jej przedmiotu ${ }^{10}$. Określenie przedmiotu umowy mającej za przedmiot przedsiębiorstwo może polegać bądź to na ogólnym posłużeniu się zwrotem przedsiębiorstwo, bądź też na wyliczeniu wnoszonych składników w sposób bezpośredni, lub przez odwołanie się do innych dokumentów ${ }^{11}$.

$\mathrm{Na}$ gruncie ustaw regulujących podatki dochodowe dla uznania, że dana masa majątkowa stanowi przedsiębiorstwo, nie jest konieczne, aby wraz z jej nabyciem doszło do przejęcia zobowiązań i ciężarów. Od dnia 25 stycznia 2003 roku $^{12}$ poza zakresem przedsiębiorstwa znajdują się zobowiązania i ciężary związane z jego prowadzeniem, więc tym samym w jego skład nie mogą wchodzić długi ${ }^{13}$.W ten sposób ustawodawca nawiązał do wąskiego rozumienia majątku, zgodnie z którym majątek przedsiębiorstwa obejmuje jedynie jego aktywa. Dokonana tą nowelizacją zmiana brzmienia przepisu jest istotna, gdyż na pierwszym miejscu pojawiają się składniki niematerialne. W kodeksowej definicji przedsiębiorstwa w zespole składników przeważa pierwiastek niematerialny ${ }^{14}$. Taka kolejność służy podkreśleniu roli, jaką odgrywają obecnie składniki niematerialne w działalności gospodarczej ${ }^{15}$. Elementy niematerialne przedsiębiorstwa stanowią w szczególności: jego renoma, prestiż, klientela, pozycja na rynku.

7 Cf. Wyrok SN z dnia 6 lipca 2005 r. sygn. III CK 705/04.

8 Vid. Wyrok WSA we Wrocławiu z dnia 6 czerwca 2008 r. sygn. I SA/Wr 355/08.

9 Cf. Wyrok WSA w Gdańsku z dnia 19 października 2011 r. sygn. I SA/Gd 737/11.

10 Wyrok SN z dnia 17 października 2000 r. sygn. I CKN 850/98.

11 Wyrok SN z dnia 8 kwietnia 2003 r. sygn. IV CKN 51/01.

12 Zmiana kodeksowej definicji przedsiębiorstwa nastąpiła mocą ustawy z dnia 14 lutego $2003 \mathrm{r}$. o zmianie ustawy - Kodeks cywilny oraz niektórych innych ustaw (Dz. U. Nr 49, poz. 408).

13 Postanowienie SN z dnia 20 października 2011 r. sygn. IV CSK 53/11.

14 Vid. M. Safjan, W. J. Katner et. al., System Prawa Prywatnego tom 1, Warszawa 2012, s. 1350.

15 Cf. E. Skowrońska-Bocian, [w:] Kodeks cywilny. Komentarz do art. 1-449 [10], t. I, red. K. Pietrzykowski, Warszawa 2011, s. 279. 


\section{Zorganizowana część przedsiębiorstwa - kryteria wyodrębnienia}

Analizując pojęcie zorganizowanej części przedsiębiorstwa, należy zauważyć, że pojęcie to bazuje na kodeksowym pojęciu przedsiębiorstwa. W doktrynie zauważa się, że ustawodawca, definiując zorganizowaną część przedsiębiorstwa, stworzył niezależną definicję na potrzeby tej ustawy oraz że prowadzi to do pewnych nieścisłości ${ }^{16}$. Zostaną one omówione poniżej. Posługiwanie się na gruncie prawa podatkowego pojęciem zorganizowanej części przedsiębiorstwa wydaje się wątpliwe - skoro dany podmiot może posiadać prawa do kilku przedsiębiorstw, to niecelowe wydaje się zaciemnianie tego pojęcia. W piśmiennictwie trafnie zauważa się, że tworzenie odrębnego pojęcia „zorganizowanej części przedsiębiorstwa" jest niepotrzebne, bowiem prawo cywilne dopuszcza istnienie wielu przedsiębiorstw w ramach jednego przedsiębiorcy ${ }^{17}$, jednakże nie sposób ignorować je w obecnym stanie prawnym. W orzecznictwie sądowoadministracyjnym podnosi się, że aby daną masę majątkową można było uznać za zorganizowaną część przedsiębiorstwa, konieczne jest wyodrębnienie jej na płaszczyźnie funkcjonalnej, organizacyjnej i finansowej ${ }^{18}$. Kluczowe jest, aby wszystkie te odrębności wystąpiły łącznie, a brak odrębności na jakimkolwiek z tych pól wyklucza możliwość uznania danej masy majątku za zorganizowaną część przedsiębiorstwa ${ }^{19}$.

Wyodrębnienie organizacyjne odnosi się do wewnętrznej struktury danego przedsiębiorstwa. W odniesieniu do tego kryterium prawo nie ustanawia żadnych precyzyjnych wymogów. Przykładowo o wyodrębnieniu organizacyjnym możemy mówić w przypadku, gdy dana masa majątkowa była przeznaczona na potrzeby określonego działu, zakładu bądź filii przedsiębiorstwa, realizującego określone, wyodrębnione czynności w ramach prowadzonej przez przedsiębiorcę działalności gospodarczej. Argumentem przemawiającym na rzecz uznania, że w danej sprawie mamy do czynienia $z$ wyodrębnieniem organizacyjnym, może być odpowiedni zapis w statucie lub umowie regulującej działalność określonego podmiotu.

Wyodrębnienia finansowego nie należy utożsamiać z samodzielnością finansową, ponieważ trudno uznać, aby warunek ten mógł być spełniony przez jednostkę wchodzącą w skład istniejącego przedsiębiorstwa. Wyodrębnienie finansowe oznacza takie prowadzenie ksiąg podatkowych (a w szczególności ksiąg rachunkowych), gdzie zdarzenia gospodarcze są rejestrowane w odniesieniu do danej masy majątkowej, z którą są związane. Przepisy o rachunkowości pozwalają na tworzenie oddziałów samobilansujących się w każdej jednostce gospodarczej ${ }^{20}$. W takiej sytuacji jednostka, w skład której

16 Podatek dochodowy od osób fizycznych. Komentarz, red. J. Marciniuk, Warszawa 2014, s. 36.

17 W. Dmoch, T. Szymura, Podatek dochodowy od osób fizycznych. Komentarz, Warszawa 2008, s. 25.

18 Wyrok NSA z dnia 12 maja 2011 r. sygn. II FSK 2222/09.

19 Cf. Wyrok WSA w Rzeszowie z dnia 9 kwietnia 2013 r. sygn. I SA/Rz 120/13.

20 A. Wencel et. al., Ustawa o rachunkowości. Komentarz, red. E. Walińska, Warszawa 2013, s. 574. 
wchodzą takie oddziały, zobowiązana jest do sporządzenia na koniec roku obrotowego łącznego sprawozdania finansowego. Problematyczne będzie jednak spełnienie wymogu wyodrębnienia finansowego w sytuacji, gdy podatnik nie prowadzi ksiąg rachunkowych, a jedynie podatkową księge przychodów i rozchodów. W takiej sytuacji nie ma prawnej możliwości prowadzenia osobnych ksiąg przychodów i rozchodów dla każdego z oddziałów. W orzecznictwie pojawia się niekorzystne dla podatników twierdzenie, że o wyodrębnieniu finansowym nie może przesądzać fakt prowadzenia dla wydziału odrębnych kont w celu ewidencjonowania operacji związanych z jego działalnością ${ }^{21}$. Przy takim rozumieniu tego kryterium jest ono najostrzejszym spośród wszystkich. Stanowisko wyrażone w powołanym orzeczeniu jest jednak zbyt rygorystyczne. Za wystarczające należałoby uznać, że z wyodrębnieniem finansowym mamy do czynienia w sytuacji, gdy podmiot prowadzi ewidencję zdarzeń gospodarczych umożliwiającą przypisanie dla danej części przedsiębiorstwa określonych przychodów i kosztów w oparciu o jakiekolwiek rozwiązania techniczne, niekoniecznie w oparciu o sporządzanie dla wyodrębnionej części przedsiębiorstwa osobnego bilansu. Również w doktrynie podnosi się, że dla zaistnienia wyodrębnienia finansowego wystarczy wskazanie istnienia jakichkolwiek przejawów odrębności finansowej od pozostałej części przedsiębiorstwa ${ }^{22}$. Pozbawienie podatnika prawa do uznania części jego przedsiębiorstwa za jego zorganizowaną część jedynie na skutek braku stosowania wyodrębnionej rachunkowości stanowi przejaw zbyt restrykcyjnej wykładni prawa.

O wyodrębnieniu funkcjonalnym można mówić w sytuacji, kiedy określona masa składników majątkowych jest w danym przedsiębiorstwie wykorzystywana do realizacji określonych celów gospodarczych danego przedsiębiorstwa. Składniki zorganizowanej części przedsiębiorstwa $-\mathrm{z}$ gospodarczego punktu widzenia - muszą stanowić pełną całość.

Co szczególnie istotne, wyodrębnienie na wszystkich trzech wskazanych płaszczyznach musi zaistnieć przed dokonaniem czynności prawnej, która ma za przedmiot określone składniki majątkowe. Wyodrębnienie musi zgodnie z definicją ustawową zaistnieć już na etapie istniejącego przedsiębiorstwa. Nie jest w tej mierze wystarczająca potencjalna możliwość wyodrębnienia danej masy majątkowej na trzech wyżej wymienionych płaszczyznach. Dopiero wyodrębnienie danej masy majątkowej uprawnia do zastanawiania się nad tym, czy tak wyodrębniona masa może stanowić niezależne przedsiębiorstwo samodzielnie realizujące zadania gospodarcze.

21 Wyrok NSA z dnia 5 lipca 2007 r. sygn. II FSK 874/06.

22 A. Mariański, D. Strzelec, M. Wilk, Podatek dochodowy od osób prawnych. Komentarz, Warszawa 2012, s. 56. 


\section{Zobowiązania związane ze zorganizowaną częścią przedsiębiorstwa - wadliwość definicji zorganizowanej części przedsiębiorstwa}

Warto w tym miejscu zaznaczyć, że na ustawową definicję zorganizowanej części przedsiębiorstwa składają się elementy materialne i niematerialne, w tym zobowiązania. Natomiast - jak już wcześniej wspomniano - w definicji przedsiębiorstwa $\mathrm{z}$ k. c. nie mieszczą się obecnie zobowiązania ani obciążenia związane $z$ jego prowadzeniem. Krytycznie należy ocenić posłużenie się przez ustawodawcę w definicji zorganizowanej części przedsiębiorstwa zwrotem „w tym zobowiązania”, gdyż sugeruje ono, że zobowiązania należą niejako do oczywistych elementów niematerialnych, które składają się na przedsiębiorstwo. Jednakże na gruncie prawa cywilnego, definiując przedsiębiorstwo, ustawodawca również posłużył się pojęciem składników niematerialnych. Pomimo to cywilistyczna definicja przedsiębiorstwa, której stosowanie na gruncie ustaw o podatkach dochodowych jest konieczne ze względu na wyraźne do niej odesłanie, nie zawiera w sobie zobowiązań. Dodatkowych wątpliwości nasuwa fakt, że dla przyjęcia, iż mamy do czynienia ze zorganizowaną częścią przedsiębiorstwa, musimy wyodrębnić określony zespół składników materialnych i niematerialnych, do których zaliczają się zobowiązania w istniejącym już przedsiębiorstwie. W skład przedsiębiorstwa - na mocy definicji prawa cywilnego, do jakiej odsyłają przepisy ustaw o podatkach dochodowych - nie moga jednak wchodzić zobowiązania. Tak sformułowana definicja zorganizowanej części przedsiębiorstwa daleka jest od standardów poprawnej legislacji. Jedynym - jak się wydaje - wyjściem z tej sytuacji jest przyjęcie, że pojęcie składników niematerialnych, o których mowa w definicji zorganizowanej części przedsiębiorstwa, jest szersze od pojęcia składników niematerialnych, o których mowa w art. 551 k. c. Definicja zorganizowanej części przedsiębiorstwa ujmuje zatem majątek w znaczeniu szerokim, a więc jako sumę zarówno aktywów, jak i zobowiązań.

W doktrynie można spotkać się z poglądem, że skoro zobowiązania stanowią cześć składników majątkowych tworzących zorganizowaną część przedsiębiorstwa, to są one składnikami majątku samego przedsiębiorstwa, obejmującego swoim zakresem wyodrębnione $z$ niego organizacyjnie i finansowo elementy ${ }^{23}$. Pogląd taki jest nie do zaakceptowania, gdyż ignoruje on w całości cywilistyczną definicję przedsiębiorstwa, do której to wprost odsyłają ustawy regulujące podatki dochodowe. Wykładnia literalna i historyczna biorąca pod uwagę dokonaną nowelizację art. $551 \mathrm{k}$. c. jednoznacznie wskazuje, że w obecnym stanie prawnym w skład przedsiębiorstwa nie wchodzą zobowiązania. Próba wyprowadzania z definicji zorganizowanej części przedsiębiorstwa definicji przedsiębiorstwa na potrzeby ustawy regulującej podatek dochodowy jest nieuprawniona w obliczu faktu jego zdefiniowana przez ustawodawcę.

23 P. Małecki, M. Mazurkiewicz, CIT. Podatki i rachunkowość. Komentarz, Warszawa 2013, s. 88. 
Za nieuprawniony należy zatem uznać pogląd, zgodnie z którym przedsiębiorstwo należy kojarzyć nie tylko z aktywami, ale również ciążącymi na tym majątku zobowiązaniami. Za błąd należy również uznać utożsamianie składników majątkowych zdefiniowanych w ustawach dochodowych jako aktywa w rozumieniu ustawy o rachunkowości, skorygowanych ewentualnie o wartość długów związanych funkcjonalnie z prowadzoną działalnością gospodarczą zbywcy, o ile długi nie zostały uwzględnione w cenie nabycia przedsiębiorstwa, $z$ pojęciem składników materialnych i niematerialnych w rozumieniu prawa cywilnego, do którego to odwołuje się ustawa o podatkach dochodowych. Przedsiębiorstwo w znaczeniu podatkowym i cywilistycznym jest czymś więcej niż tylko sumą aktywów. Przykładowo wymienione w art. 551 k. c. księgi i dokumenty związane z prowadzeniem działalności gospodarczej a także tajemnice przedsiębiorstwa nie spełniają definicji aktywów, pomimo że na mocy wyraźnego brzmienia przepisu wchodzą one w jego skład.

Kolejnym z problemów, jaki może powstać na tle stosowania definicja zorganizowanej części przedsiębiorstwa, będzie zagadnienie, czy konieczne jest przeniesienie wszystkich zobowiązań związanych $z$ danymi składnikami majątkowymi na ich nabywcę, aby przyjąć, że na gruncie prawa podatkowego transakcja miała za przedmiot zorganizowaną część przedsiębiorstwa. W orzecznictwie sądowoadministracyjnym zaprezentowano stanowisko zgodnie z którym, definicja zorganizowanej części przedsiębiorstwa nie wymaga, aby w jego skład musiały wchodzić wszystkie zobowiązania związane z daną częścią przedsiębiorstwa ${ }^{24}$. Co szczególnie interesujące, w wyroku tym sąd doszedł do wniosku, że, poprzestając na wykładni gramatycznej, należałoby uznać, iż brak zobowiązań powoduje, że nie można mówić o zorganizowanej części przedsiębiorstwa. Odwołując się jednak do reguł wykładni celowościowej, uznano, że fakt braku zobowiązań nie może pozbawiać danego zespołu składników majątkowych statusu zorganizowanej części przedsiębiorstwa $z$ tego względu, że zobowiązań takich może nie być na skutek ich wcześniejszej spłaty. $\mathrm{O}$ ile pogląd ten zasługuje na pełną aprobatę z praktycznego punktu widzenia, to jednak w ujęciu teoretycznym sąd odstąpił od literalnej wykładni definicji, dając prymat wykładni funkcjonalnej, a postępowanie takie jest niedopuszczalne w świetle derywacyjnej koncepcji wykładni prawa.

Dodatkowych wątpliwości w przypadku przeniesienia zobowiązań nastręcza fakt, iż zgodnie z art. 519 k. c. osoba trzecia może wstąpić w miejsce dłużnika, jednak do przejęcia długu konieczna jest umowa pomiędzy wierzycielem a osobą trzecią zawarta za zgodą dłużnika albo umowa pomiędzy dłużnikiem a osobą trzecią za zgodą wierzyciela. W przypadku zbycia zorganizowanej części przedsiębiorstwa stosowanie tych regulacji byłoby bardzo uciążliwe. Co więcej, brak zgody wierzyciela powodowałby, że nie można byłoby mówić o transakcji mającej za przedmiot zorganizowaną część przedsiębiorstwa. Wyjściem z tego może być zawarcie pomiędzy nabywcą a zbywcą zorganizowanej części

24 Cf. Wyrok WSA w Warszawie z dnia 28 kwietnia 2011 r. sygn. III SA/Wa 1767/10. 
przedsiębiorstwa umowy o zwolnienie $\mathrm{z}$ długu, dla której to zawarcia podstawę stanowi art. 392 k. c. W jej wyniku nie dochodzi do przejęcia wierzytelności, a jedynie do powstania nowego zobowiązania, którego treścią jest obowiązek osoby trzeciej zwolnienia dłużnika od obowiązku świadczenia na rzecz jej wierzyciela. Rozwiązanie takie - ze względu na prostotę i brak wymogu zgody dotychczasowego wierzyciela - zdaje się prostsze do stosowania. Jednakże jeśli patrzy się na to zagadnienie z punktu widzenia wykładni literalnej, nasuwa się wniosek, że poprzez zawarcie umowy o zwolnienie z długu nie następuje przejście zobowiązania na rzecz nabywcy. Wydaje się, że w tym miejscu należy również dać posłuch wykładni celowościowej, dopuszczającej, że taka umowa będzie wystarczającą podstawą dla uznania, że w skład danej masy majątkowej wchodzą także zobowiązania. Zakładając bowiem lojalność nabywcy, poniesie on ekonomiczny ciężar spłaty tych zobowiązań. W takim przypadku jego sytuacja będzie bardzo zbliżona do sytuacji nabywcy, który przejął na siebie obowiązek uregulowania długów w drodze cesji.

\section{Prawa do nieruchomości a zorganizowana część przedsiębiorstwa}

W orzecznictwie przyjmuje się, że wykładnia definicji zorganizowanej części przedsiębiorstwa nie daje podstaw dla przyjęcia, iż w jego skład musi wchodzić prawo do nieruchomości na których to działalność gospodarcza ma być prowadzona ${ }^{25}$. Podkreśla się, że prawo do korzystania $z$ nieruchomości można uzyskać także na podstawie odpłatnego posiadania zależnego (wynajem, dzierżawa, leasing) ${ }^{26}$. Pogląd ten należy uznać za w pełni zasadny, a wskazówką w tym zakresie mogą być przepisy k. c. W art. 551 pkt. 2 mowa jest co prawda, że w skład przedsiębiorstwa wchodzi również własność nieruchomości oraz inne prawa rzeczowe do nieruchomości, jednak pamiętać należy, że jest to jedynie wyliczenie przykładowe. Jak wspomniano wcześniej, orzecznictwo stanowi, że minimum składników materialnych i niematerialnych, przy których przeniesieniu można mówić, że przedmiotem czynności jest przedsiębiorstwo, stanowią te składniki konieczne dla podjęcia działalności gospodarczej. Co więcej, art. 751 § 1 k. c. stanowi, że zbycie przedsiębiorstwa powinno być dokonane w formie pisemnej z podpisami notarialnie poświadczonymi. Zgodnie jednak z $\S 4$ przepis ten nie uchybia przepisom o formie czynności prawnych dotyczących nieruchomości. Gdyby przyjąć, że nie można mówić o przedsiębiorstwie, jeżeli dana masa nie zawiera praw do nieruchomości, to postanowienia $\S 1$ byłby całkowicie zbędne. Oczywiste jest jednak, że taka wykładnia jest niedopuszczalna.

25 Cf. Wyrok NSA z dnia 30 sierpnia 2011 r. sygn. II FSK 502/10.

26 Cf. Wyrok WSA w Poznaniu z dnia 21 kwietnia 2010 r. sygn. I SA/Po 132/10. 
144 | Adam Mickiewicz University Law Review

\section{Przedsiębiorstwo i zorganizowana część przedsiębiorstwa na gruncie ustawy o podatku od towarów i usług}

\section{Rozumienie pojęcia przedsiębiorstwa oraz definicja jego zorganizowanej części}

Ustawa o podatku od towarów i usług, pomimo posługiwania się pojęciem przedsiębiorstwa, nie zawiera jego definicji. Pojęcie zorganizowanej części przedsiębiorstwa na potrzeby tego aktu prawnego jest identyczne ze znaczeniem, jakie to pojęcie ma na gruncie ustaw o podatkach dochodowych.

Praktyczne znaczenie pojęcia przedsiębiorstwa i zorganizowanej części przedsiębiorstwa uwidacznia się w sytuacji ich zbycia, zgodnie bowiem z art. 6 pkt. 1 postanowień ustawy o podatku od towarów i usług nie stosuje się do transakcji zbycia przedsiębiorstwa lub zorganizowanej części przedsiębiorstwa. W przepisie tym zawarto wyłączenie czynności zbycia, mającej za przedmiot przedsiębiorstwo lub jego zorganizowaną część. Co ciekawe, w powyższym przepisie ustawodawca posłużył się określeniem „transakcji zbycia”, a nie charakterystycznym dla tej ustawy pojęciem sprzedaży bądź też dostawy towarów, które to pojęcia są autonomiczne względem pojęć z prawa cywilnego. Ma to taki skutek, że wyłączenie będzie stosowane jedynie do czynności rozporządzających mających za przedmiot przedsiębiorstwo lub jego zorganizowaną część. Wyłączenie nie znajdzie zastosowania przykładowo do umów oddania przedsiębiorstwa do odpłatnego korzystania.

Pojęcie przedsiębiorstwa, pomimo braku definicji legalnej, rozumiane jest zgodnie $z$ jego znaczeniem w prawie cywilnym, a więc w znaczeniu przedmiotowym ${ }^{27}$. W jednym $z$ orzeczeń ${ }^{28}$ uznano, że aby na gruncie przepisów ustawy o podatku od towarów i usług mówić o przedsiębiorstwie konieczne jest, aby dany zespół składników majątkowych i niemajątkowych tworzył przedsiębiorstwo już u jego zbywcy. W tym samym orzeczeniu przyjęto, że aby mówić o transakcji zbycia przedsiębiorstwa, konieczne jest zbycie minimum składników majątku koniecznych dla realizacji zadań gospodarczych.

Z 1 grudnia 2008 roku dokonano nowelizacji ustawy, dodając do niej pojęcie zorganizowanej części przedsiębiorstwa, wprowadzono jednocześnie wyłącznie dla czynności jego zbycia. Przed tym dniem zwolnienie to, oprócz przedsiębiorstwa, obejmowało także zbycie zakładu (oddziału) samodzielnie sporządzającego bilans - tak sformułowany zakres wyłączenia budził wątpliwości w kontekście prawa wspólnotowego. Wspomniana nowelizacja zmodyfikowała zatem zakres tego wyłączenia, ponieważ pojęcie zorganizowanej części przedsiębiorstwa jest szersze od pojęcia zakładu samodzielnie sporządzającego bilans. Stan sprzed nowelizacji budził pewne wątpliwości z tego względu, że zakład, który samodzielnie sporządza bilans, jest na ogół na tyle odrębną masą majątkową, że pozwala to na uznanie jej za przedsiębiorstwo. $\mathrm{Na}$ tle stanu prawnego sprzed nowelizacji

27 Cf. Wyrok WSA w Poznaniu z dnia 9 października 2008 r. sygn. I SA/Po 638/08.

28 Wyrok WSA w Bydgoszczy z dnia 28 maja 2008 r. sygn. I SA/Bd 135/08. 
pojęcie bilansu należało rozumieć zgodnie $z$ ustawą o rachunkowości ${ }^{29}$, a więc jako element obszerniejszego dokumentu - sprawozdania finansowego. Jednakże w drodze wykładni prowspólnotowej wywodzono, że wymóg ten jest w świetle regulacji wspólnoto-

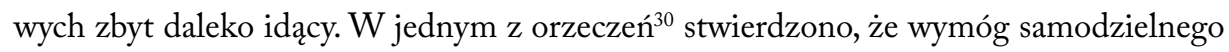
sporządzenia bilansu przez tę część przedsiębiorstwa nie powinien mieć decydującego znaczenia dla oceny, czy zachodzi wyłączenie, o którym mowa w art. 6 pkt. 1 in fine ustawy. Obecnie dla zaistnienia zorganizowanej części przedsiębiorstwa konieczne jest wyodrębnienie finansowe.

\section{Niezgodność rozwiązań przyjętych w ustawie o podatku od towarów i usług z regula- cjami Dyrektywy 2006/112}

Co szczególne dla ustawy o podatku od towarów i usług, znaczenie pojęć przedsiębiorstwa i jego zorganizowanej części musi być kompatybilne $z$ treścią i celami Dyrektywy 2006/112. Zgodnie z jej art. 19 akapitem pierwszym, w przypadku przekazania, odpłatnie lub nieodpłatnie lub jako aportu do spółki całości lub części majątku, państwa członkowskie mogą uznać, że dostawa towarów nie miała miejsca i że w takim przypadku osoba, której przekazano towary, będzie traktowana jako następca prawny przekazującego.

Zacytowany powyżej przepis dyrektywy posługuje się pojęciami całości lub części majątku. O ile pojęcie całego majątku nie budzi większych wątpliwości, o tyle brak w dyrektywie definicji, co musi obejmować cześć majątku, aby możliwe było zastosowanie do jej przekazania wyłączenia przewidzianego w przytoczonym przepisie. Wątpliwość ta została wyjaśniona przez ETS w jednym $z$ orzeczen ${ }^{31}$, gdzie uznano, że zasada wyrażona w przepisie ma zastosowanie do każdego przedsiębiorstwa lub części przedsiębiorstwa mogącego samodzielnie prowadzić działalność gospodarczą. W jednym z orzeczeń ${ }^{32}$ ETS uznał za dopuszczalne zrównanie zbycia 100\% udziałów w podmiocie zależnym z przekazaniem całości lub części majątku - co pozwala na zastosowanie do takiej czynności wyłączenia. Takie rozumienie części majątku, o którym wspomina dyrektywa, odpowiada na gruncie ustawy o podatku od towarów i usług definicji zorganizowanej części przedsiębiorstwa lub samego przedsiębiorstwa. Jak stwierdził w przytoczonym wyroku ETS, zwolnienie uwarunkowane jest od dalszego prowadzenia działalności gospodarczej przez nabywcę przy wykorzystaniu nabywanego majątku, sam zakres prowadzonej działalności nie musi być tożsamy z zakresem działalności prowadzonej przez zbywcę. Omawiane wyłączenie - zdaniem ETS - nie znajdzie zatem zastosowania w sytuacji, gdy celem nabywcy jest jedynie zlikwidowanie działalności i dalsza sprzedaż nabywanych aktywów. Zastrzeżeń takich nie zawiera jednak ustawowa definicja zorganizowanej

29 Wyrok NSA w Warszawie z dnia 6 listopada 2003 r. sygn. III SA 30/02.

30 Wyrok NSA z dnia 26 lutego 2010 r. sygn. I FSK 150/09.

31 Wyrok ETS z dnia 27 listopada 2003 r. sygn. C-497/01.

32 Wyrok ETS z dnia 29 października 2009 r. sygn. C-29/08. 
części przedsiębiorstwa, a tym bardziej zastrzeżenia takiego nie można wyrazić co do przedsiębiorstwa $z$ jego kodeksowej definicji.

Co szczególnie interesujące, przepis dyrektywy wymaga, żeby w przypadku zastosowania przez państwo członkowskie opcjonalnego zwolnienia nabywca całości lub części majątku był traktowany jako następca prawny przekazującego. Wątpliwości w tym zakresie nasuwa analiza polskiego stanu prawnego - ustawa o podatku od towarów i usług nakłada na nabywcę przedsiębiorstwa bądź jego zorganizowanej części jedynie obowiązek korekty podatku odliczonego ${ }^{33}$. Rozwiązanie takie powoduje, że zbywca przedsiębiorstwa lub jego zorganizowanej części nie jest zobligowany do dokonywania korekty podatku odliczonego $\mathrm{w}$ związku $\mathrm{z}$ dokonywaniem czynności rozporządzania towarami wchodzącymi w ich skład. Dyrektywa wymaga, aby nabywca całości lub części majątku, rozumianych na gruncie polskiej ustawy jako przedsiębiorstwo lub jego zorganizowana część był traktowany jak następca prawny. Sformułowanie to - według analizy literalnej - nie wymaga, aby nabywca był następcą prawną, a jedynie, by był traktowany w ten sposób $^{34}$. Celem tego przepisu jest jednak zagwarantowanie nabywcy przedsiębiorstwa prawa i obowiązków, które poprzednio przysługiwały zbywcy. $Z$ drugiej strony, pojęcie następstwa prawnego należy rozumieć $\mathrm{z}$ uwzględnieniem celów dyrektywy - a więc tylko jako następstwo prawne na potrzeby podatku od towarów i usług. Ustawa o podatku od towarów i usług nie traktuje nabywcy przedsiębiorstwa lub jego zorganizowanej części jak następcę prawnego zbywcy, regulacja polska nie przewiduje przykładowo, aby nabywca mógł dokonać korekty deklaracji podatkowych składanych przez zbywcę a pozostających w związku z nabytym przedsiębiorstwem albo jego zorganizowaną częścią.

$\mathrm{Na}$ gruncie Ordynacji Podatkowej ustawodawca na mocy jej art. 112 uczynił nabywcę przedsiębiorstwa lub zorganizowanej części przedsiębiorstwa odpowiedzialnym całym swoim majątkiem, solidarnie ze zbywcą za powstałe do dnia nabycia zaległości podatkowe, związane z prowadzoną działalnością gospodarczą. Odpowiedzialność ta wyłączona jest w sytuacji, gdy przy zachowaniu należytej staranności nabywca nie mógł wiedzieć o tych zaległościach. Granicę dla odpowiedzialności nabywcy stanowi wartość nabytego przedsiębiorstwa lub jego zorganizowanej części. Co istotne, odpowiedzialność ta ma charakter odpowiedzialności osoby trzeciej, nie zaś następcy prawnego. Uregulowanie odpowiedzialności tej w ramach ordynacji podatkowej skutkuje tym, że dotyczy ona wszystkich podatków, a nie jedynie podatku od towarów i usług. Co prawda dyrektywa nie stawia nabywcy wymogu bycia następcą prawną, a jedynie takiego jego traktowania. Jednak nawet takie sformułowanie nie pozwala na uznanie, że polska regulacja pozostaje zgodna z wymogami dyrektywy, bowiem dla następstwa prawnego charakterystyczna jest odpowiedzialność bez ograniczeń, a także wstąpienia w ogół praw i obowiązków. Wstąpienia w prawa zbywcy, w odniesieniu do podatku od towarów i usług, nie przewi-

33 art. 91 ust. 9 ustawy o podatku od towarów i usług.

34 tak: Wyrok NSA z dnia 30 sierpnia 2011 r. sygn. I FSK 1199/10. 
duje ustawa o podatku od towarów i usług. Taki skutek jest niemożliwy również podczas stosowania przepisów ordynacji podatkowej.

Pogląd o ułomnej implementacji dyrektywy w tym zakresie pojawia się także w orzecznictwie. W jednym $z$ orzeczeń ${ }^{35}$ stwierdzono, że ustawodawca dokonał implementacji ułomnie, jednak w drodze wykładni prowspólnotowej należy sukcesji tej nadać kształt wynikający z regulacji dyrektywy. Podkreślono przy tym, że celem takiego rozwiązania jest zachowanie zasady neutralności podatku. W przypadku zbycia przedsiębiorstwa lub zorganizowanej jego części dochodzi do sukcesji prawnopodatkowej ${ }^{36}$. Unormowania na gruncie ustawy o podatku od towarów i usług stanowią przepisy szczególne względem regulacji ordynacji podatkowej, czego konsekwencją jest możliwość korzystania przez nabywcę przedsiębiorstwa $\mathrm{z}$ uprawnień służących zbywcy ${ }^{37}$.

\section{Pojęcie przedsiębiorstwa na gruncie ustawy o podatku od czynności cywilnoprawnych}

Od 22 stycznia 2010 roku również na gruncie ustawy o podatku od czynności cywilnoprawnych występuje pojęcie przedsiębiorstwa i jego zorganizowanej części. Zgodnie $\mathrm{z}$ art. 2 pkt 6 lit. c tiret pierwszy ustawy - nie podlegają podatkowi umowy spółki i ich zmiany związane z wniesieniem do spółki kapitałowej, w zamian za jej udziały lub akcje przedsiębiorstwa spółki kapitałowej lub jego zorganizowanej części. Przed wspomnianą nowelizacją ustawa posługiwała się pojęciem oddziału spółki kapitałowej. W obecnym brzmieniu nie zawiera ona definicji ani przedsiębiorstwa ani jego zorganizowanej części.

Wprowadzone wyłączenie jest konsekwencją obowiązywania Dyrektywy 2008/7/ WE, gdyż zgodnie z jej art. 5 ust. 1 lit. e w zw. z art. 4 ust. 1 pkt. 1 - nie podlegają podatkowi spółki kapitałowe z tytułu przeniesienia przez jedną lub kilka spółek kapitałowych wszystkich swoich aktywów i pasywów lub jednego bądź więcej oddziałów do jednej lub więcej spółek kapitałowych, które są w trakcie tworzenia lub już istnieją pod warunkiem, że rekompensata obejmuje przynajmniej częściowo papiery wartościowe reprezentujące kapitał spółki przejmującej.

W piśmiennictwie podnosi się, że polskie tłumaczenie dyrektywy jest wadliwe ${ }^{38}$, bowiem angielska wersja dyrektywy posługuje się pojęciem branches of activity, które należy tłumaczyć jako gałęzie działalności. Znaczenie tego pojęcia na gruncie prawa wspólno-

35 Wyrok WSA w Warszawie z dnia 28 maja 2010 r. sygn. III SA/Wa 2081/09.

36 Wyrok NSA z dnia 28 października 2011 r. sygn. I FSK 1660/10.

37 Wyrok WSA w Białymstoku z dnia 5 lutego 2013 r. sygn. I SA/Bk 435/12.

38 A. Mariański, M. Wilk, Oddziat spótki kapitatowej na gruncie ustawy o podatku od czynności cywilnoprawnych, [w:] „Monitor Podatkowy”2009, nr 4, s. 23. 
towego zostało wyjaśnione przez jedno z orzeczeń ETS ${ }^{39}$. Trybunał wyjaśnił w nim, że pojęcie branches of activity należy rozumieć jako sumę aktywów i osób zdolnych do realizacji określonej działalności. Wyrok ten, chodź zapadł na tle dyrektywy 69/335/EWG będącej poprzedniczką obecnie obowiązującej dyrektywy 2008/7/WE, nadal zachował swoją aktualność ze względu na tożsamość pojęć.

Takie rozumienia pojęcia branches of activity pozwala w drodze wykładni prowspólnotowej na rozumienia pojęcia przedsiębiorstwa i zorganizowanej części przedsiębiorstwa w sposób autonomiczny, odmienny niż na gruncie poprzednio omówionych ustaw. Pojęcie to jest o tyle zgodne $\mathrm{z}$ pojęciem przedsiębiorstwa na gruncie polskich ustaw podatkowych, o ile na jego minimum składają się elementy niezbędne do realizacji określonej działalności gospodarczej. W przypadku pojęcia zorganizowanej części przedsiębiorstwa na gruncie ustawy o podatku od czynności cywilnoprawnych, nie wydaje się konieczne wyodrębnienie organizacyjne i finansowe. Wystarczające dla uznania, że mamy do czynienia ze zorganizowaną częścią przedsiębiorstwa, będzie ustalenie, iż dana masa majątkowa obejmuje sumę aktywów zdolnych do realizacji określonych zadań. Odwołanie się w drodze wykładni systemowej zewnętrznej do definicji przedsiębiorstwa i zorganizowanej części przedsiębiorstwa bez uwzględnienia wspólnotowego znaczenia komentowanych pojęć należy uznać za niedopuszczalne. Taki zabieg interpretacyjny ignorowałby bowiem treść interpretowanego pojęcia na gruncie prawa wspólnotowego.

\section{Podsumowanie}

Pojęcie przedsiębiorstwa na gruncie prawa podatkowego jest rozumiane niemalże identycznie jak na gruncie prawa cywilnego. $\mathrm{O}$ ile stan ten w przypadku ustaw regulujących podatki dochodowe nie powoduje żadnych komplikacji, o tyle już na gruncie ustawy o podatku od towarów i usług brak autonomicznej definicji przedsiębiorstwa może być przyczynkiem dla kwestionowania jej zgodności z prawem unijnym. W szczególności należy zwrócić uwagę na to, że ustawodawca nie wywiązał się z obowiązku traktowania nabywcy przedsiębiorstwa jako następcy prawnego zbywcy na potrzeby rozliczeń tego podatku.

Pojęcie zorganizowanej części przedsiębiorstwa identycznie zdefiniowane na gruncie ustaw regulujących podatki dochodowe i ustawy o podatku od towarów i usług jest zdefiniowane w sposób wadliwy, nie uwzględniający faktu, że w skład istniejącego przedsiębiorstwa $\mathrm{w}$ świetle jego ujęcia $\mathrm{w}$ prawie cywilnym zgodnie $\mathrm{z}$ wąską koncepcją majątku nie mogą wchodzić zobowiązania. Rozwiązywanie tego rodzaju niezgodności wymaga od podmiotów stosujących prawo, w tym zwłaszcza od sądów administracyjnych kontro-

39 Wyrok ETS z dnia 13 października 1992 r. C-50/91. 
lujących legalność działania administracji, uciekania się do reguł wykładni funkcjonalnej oraz odstępowania na jej rzecz od wyników wykładni językowej. Jak trafnie wskazuje doktryna włączenie do definicji zorganizowanej części przedsiębiorstwa zobowiązań doprowadziło do zbędnych komplikacji interpretacyjnych ${ }^{40}$.

W ocenie autora wątpliwa jest konieczność funkcjonowania na gruncie ustaw podatkowych pojęcia „zorganizowana część przedsiębiorstwa”. Pojęcie przedsiębiorstwa funkcjonujące na obszarze prawa podatkowego, a zaczerpnięte z prawa cywilnego dopuszcza możliwość posiadania przez jeden podmiot prawa kilku przedsiębiorstw. Mając to na uwadze, należy uznać że pojęcie przedsiębiorstwa stwarza dostateczne możliwości dla obrotu zorganizowanymi i funkcjonalnie powiązanymi wartościami niematerialnymi i materialnymi, które mogą w obrocie gospodarczym służyć za podstawę dla prowadzenia działalności gospodarczej. Jednak wobec aktualnego kształtu omawianych przepisów, należy wskazać, że definicja zorganizowanej części przedsiębiorstwa wymaga zmiany polegającej na usunięciu $\mathrm{z}$ ustawowej definicji zwrotu „w tym zobowiązania”. Tylko taki zabieg legislacyjny jest w stanie usunąć niezgodność występującą obecnie pomiędzy pojęciami przedsiębiorstwo a zorganizowana część przedsiębiorstwa.

Pojęcie przedsiębiorstwa i zorganizowanej części przedsiębiorstwa na gruncie ustawy o podatku od czynności cywilnoprawnych należy rozumieć w sposób autonomiczny, odbiegający od definicji zawartych w innych ustawach podatkowych, co jest wynikiem orzecznictwa ETS. W szczególności zorganizowana cześć przedsiębiorstwa nie musi spełniać kryterium wyodrębnienia organizacyjnego i finansowego. Również ta kwestia powinna zostać uregulowana w zapisach polskiej ustawie o podatku od czynności cywilnoprawnych poprzez wprowadzenie do niej definicji przedsiębiorstwa i jego zorganizowanej części uwzględniającej wskazówki płynące z dotychczasowego orzecznictwa ETS. Definicje te nie mogą jednak odpowiadać definicjom omawianych pojęć, które funkcjonują na gruncie wyżej wspomnianych ustaw podatkowych.

\section{SUMMARY}

\section{The concept of an enterprise and the concept of an organized part of an enterprise in Polish tax legislation}

The purpose of this study was a presentation of the concept of an enterprise and the concept of an organized part of an enterprise in Polish tax legislation. The study focused on The Personal Income Tax Act, The Corporate Income Tax Act, The Goods and Services Tax Act and The Tax on Civil Law Transactions Act. An interpretation of the aforementioned concepts in the jurisdiction of Polish courts was also presented. Furthermore,

40 K. Serwińska, PIT. Komentarz praktyczny, red. J. Narkiewicz-Tarłowska, Warszawa 2014, komentarz elektroniczny, dostępny w bazie danych Legalis. 
150 | Adam Mickiewicz University Law Review

another aim was to look at the concept of an enterprise and the concept of an organized part of an enterprise from the point of view of European Union law. The study also tried to answer the question of whether The Goods and Services Tax Act and The Tax on Civil Law Transactions Act are compatible with European Union law.

Keywords: Financial law, the concept of an enterprise, the concept of an organized part of an enterprise 